\title{
Learning at Tanta University During the Covid-19 Pandemic
}

\author{
Dr. Mohamed Abdullah Turky ${ }^{1}$, Dr. Amir Shahin ${ }^{2}$, Nardeen Soliman ${ }^{3}$ \\ ${ }^{1}$ Digital Design and Publishing Research Unit (DDPRU), Faculty of Education, Tanta University, Egypt \\ ${ }^{2}$ Digital Design and Publishing Research Unit (DDPRU), Faculty of Education, Tanta University, Egypt \\ ${ }^{3}$ Demonstrators, Department of Mental Health, Faculty of Education - Tanta University, Egypt
}

\begin{abstract}
The pandemic of coronavirus has had a major effect on teaching. Crisis Meant Teachers Across The Globe Had To Adapt Rapidly And Switch To Remote Teaching. This paper explores the useful methods of instruction used at the Faculty of Education (Egypt) of the University of Tanta during the crisis. It also provides suggestions for improving the educational and learning experiences of students in a pandemic setting. and Offers Easy Knowledge of Coronavirus As Well..
\end{abstract}

Keywords: Learning-Covid-19-coronavirus - SARS-CoV-2 - Pandemic - Tanta University.

\section{Introduction}

\section{Coronavirus virus}

Most Parts of The Human Body May Be Infected By Coronavirus, and Infection Symptoms Vary From Person To Person. Some General Ones Are Cough, Stomach Issues, Trouble Breathing, Fever And Loss of Taste And Odor [1]. It Is Mainly Distributed Among People In Close Contact With The Virus, And Droplets From Coughs, Sneezes, Etc. COVID19 Is Caused By Severe Acute Respiratory Syndromes From Coronavirus 2 (SARS-Cov-2) Infections [2].

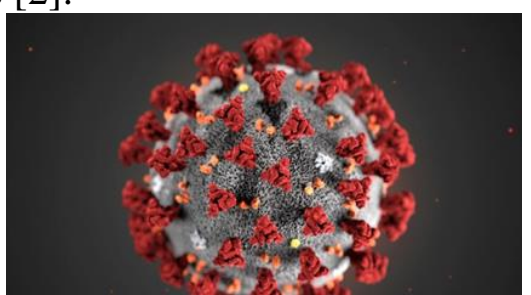

Figure (1) (Covid-19) Centers for Disease Control and Prevention https://news.un.org/ ar/focus/fyrws-lkwrwn-covid-19

\section{Zoom}

Zoom Was Used For Audio / Video Briefing Sessions, Training In the Classroom, Working
Hours, Presentations of Students, Etc. Participants Were Recruited By Way of Email Invitations. Instructors Would Silence Others If They Desired To Prevent Distracting Background Noise, or Only Silence and Discouragement. You Can Select Views From The Screen To Show All At Once, or Just The Person Speaking. This Platform Allowed Instructors To Meet Online Students (A Virtual Face-To - Face) and Offer Lessons At Regularly Scheduled Class Times Per Week As Synchronous Instruction. Some Classes Were Asynchronous, With The Students Doing Their Own Assignments And Lessons [3].

\section{Microsoft Teams}

Microsoft Teams Have Been Used For Variety of Activities, It Has Built-In Meeting Functionality To Easily Conduct Lessons, And Share Documents (Using Postings To Link Power Point Presentations, Interactive Websites, Videos, E-Books, Etc.). Interactive Whiteboards, And Video Calls [4] Are Also Available. A Multi-Part Note-Taking Process (One Note) Is Incorporated Into the Teams For 
A Variety of Lessons And Events. By Using This Method The Faculty And Students Are Part of Teams Such As Several STEM Squads. The Faculty Member Has Its Own Classroom Forum, Etc., And The Potential to Reach Networks of other Individuals for Joint Ventures, Etc.[5].

\section{Slides Graphics}

During The Pandemic The Third Possible Teaching Method Is A Slides Graphics Device. Slides Graphics Is The Use Of Game Design Elements From A Gaming World. Through Stimulating, Award-Winning Problem-Solving Exercises, This Technology Encourages Enjoyable Learning [6].

\section{LMS (Moodle)}

International Higher Education Institutions Have Recognized The Need To Implement And Incorporate Information And Communication Technology To Tackle The Possibilities And Barriers To Transition In Teaching And Learning Processes. This Principle Has Contributed To The Implementation For The 'Learning Management Systems' In Virtual Learning Environments [7]. From A Functional Perspective, The Moodle Framework Has Easily Configurable Features That Allow For The Generation And Management Of Student Assessment Processes (Questionnaires And Online Tests)[8].

Studies have confirmed for about effectiveness of video and images as well as educational platforms in increasing motivation to learn in electronic environments [9]. and use of taskbased video within educational platforms helps in learning Faculties of Education students. for achieve various learning outcomes, and when changing the way to use web-based environments, helps in upgrade the content of the curricula and employ images of different elements in electronic environments[10].

\section{Methodology}

The coronavirus pandemic significantly impacted teaching. The crisis meant instructors had to rapidly adjust to remote teaching and move on. The Faculty of Education at Tanta University had no advance warning that after the spring break in March 2020 they will be forced to teach their courses online. Their colleges immediately closed during the break and permitted only critical staff on campus (such as security, information technology personnel, etc.). The lockout was in place at this time. Students had an extra spring holiday week, so that teachers May have a few days to schedule online courses. These students were not allowed to get back to the campus (except for retrieving their belongings several months later). A limited number of them were allowed to remain in the campus dorms (no place to go) until the end of the semester.

\section{Lockdown time}

Only about everything had been locked during lockout. Storehouses were also open that sold food and medicine. People were advised to stay at home and just go out to buy food and medication to help prevent and delay the spread of the virus. They were strongly encouraged to wear masks (especially inside buildings), wash their hands constantly with soap and warm water and keep a social distance of six feet from other people. During lockdown the teaching proceeded. Since all Faculties at Tanta University Locked, teachers and parents (working from home) had to look after their children and support them with their studies and lessons online. Many people have had the following problems: loss of a business, loss of a job, loss of income, loss of a home, corona virus sickness or some other illness, etc. Notice that the students' lives have changed greatly. Instead of being in a classroom and living without activities, they had to adjust to online learning and social gatherings with friends and the perks of college life,

\section{Pandemic learning approaches \& instruction}

Members of the faculty Share their tales of distant teaching during a pandemic. Primarily included the Zoom and Microsoft Teams and LMS (Moodle System). However, as experts at teaching classes with Slides, they were also prepared to use this method (which is a type of Graphic). Professors in the Faculty of Education, University of Tanta were permitted to continue their work in the college laboratories in carrying 
out research activities. Researchers in the state of Tanta University, on the other hand, were not allowed on campus during the lockdown according to table (1):-

Table (1) list of courses and lectures uploaded on ( Microsoft Team - Zoom - Moodle)

\begin{tabular}{|c|c|c|}
\hline Department & Courses & lectures \\
\hline Mental Health & 35 & 80 \\
\hline Psychology & 15 & 40 \\
\hline Curriculum \& Teaching Methods' & 90 & 360 \\
\hline Arabic Language & 28 & 55 \\
\hline Foreign Language & 20 & 100 \\
\hline Educational Management & 25 & 70 \\
\hline Kindergarten & 30 & 71 \\
\hline Educational Comparative & 30 & 65 \\
\hline Total & 273 & 841 \\
\hline
\end{tabular}

Table (2) Total (courses and lectures and Student ) Final semester ( Jun ,2020)

\begin{tabular}{|l|l|}
\hline Axis & Total \\
\hline Courses & 815 \\
\hline Student Input Courses & 804 \\
\hline Uploaded lectures on Courses & 804 \\
\hline Student & 11816 \\
\hline Student Signup on Courses & 10698 \\
\hline Student Uploaded Assignment on Courses & 9466 \\
\hline
\end{tabular}

\section{Discussion}

Through analyzing the previous Static found:-

- Teach with an ambitious positive attitude and focus on supporting students rather than rigorous teaching. Be versatile as some students may get sick with the virus and/or their parents may have lost their jobs, wages etc. Bear in mind that certain students don't have computer and internet access.

- Tools make Student more Active and Responsibility for their Learning.

- Distance Learning good Way for learning any time any place even in the war and Pandemic's

\section{Conclusion}

We conclude with some recommendations to enhance the learning conditions of one's teaching and the students during the pandemic. Whatever online teaching tool you want to use, it is important that students are versatile and voice their concern. Email and inform your class members that you are available to assist them, and encourage them to ask questions whenever possible. Teach with an ambitious positive attitude and focus on supporting students rather than rigorous teaching. Be versatile as some students may get sick with the virus and/or their parents may have lost their jobs, wages etc. Bear in mind that certain students don't have computer and internet access etc. But to enhance their learning special modifications will be required. Often request permission to substitute one subject (example: from a college dean) which is too difficult for students to learn online in a curriculum. It's interesting to note that colleges at the Faculty of Education at Tanta University and others have allowed students to select a "pass / fail" rather than a standard letter or number grade. Several online lessons were provided for university students in Egypt along with packets of learning materials. However teachers were not allowed to rate their work.

\section{Acknowledgements}

Finally, I thank my colleagues in the Research and Design and Digital Publishing Unit for their moral support to me in carrying out this study, and also thank the graduate students who specialize in educational technology for their perseverance during the application of the study.

\section{References}

[1] heng H-Y, Jian S-W, et al(2020). Contact Tracing Assessment of COVID-19 Transmission Dynamics in Taiwan and Risk at Different Exposure Periods Before and After Symptom Onset. JAMA Intern Med. 2020; e202020.

[2] Scientific Brief. (who.int) Transmission of SARS-CoV-2: implications for infection prevention precautions (2020). World Health Origination - $\quad$ https://www.who.int/newsroom/commentaries/detail/transmission-of-sarscov-2-implications-for-infection-preventionprecautions

[3] Bellan, Rebecca (March 24, 2020). What You Need to Know about Using Zoom, Forbes. https://www.forbes.com/sites/rebeccabellan/202 0/03/24/what-you-need-to-know-about-usingzoom/\#439e80df3284

[4] Microsoft Teams ..https://docs.microsoft.com/enus/microsoftteams/teams-overview 
[5] Barry, D.M. Kanematsu, H. Lawson, M. Nakahira, K. and Ogawa, N. (2017) Virtual STEM Activity for Renewable Energy, Procedia Computer Science, 112, pp. 946-955.

[6] Melian-Melian, Juan A.; Martin-Gutierrez, Jorge (2020). Influence of Learning Objects of Graphics Architecture on Motivation , SAGE Open, v10 n2 Apr-Jun 2020 https://journals.sagepub.com/doi/10.1177/2158 $\underline{244020935886}$

[7] Cabero-Almenara, Julio; Arancibia, Maria Luisa(2020). Technical and Didactic Knowledge of the Moodle LMS in Higher Education. Beyond Functional Use, Journal of New Approaches in Educational Research, v8 n1 p25-33 Jan 2019, http://files.eric.ed.gov/fulltext/EJ1202917.pdf

[8] Turky, M., Soliman, N. (2020). Developing autoDidactic (Self-Learning) Skills by Using Social Networking. International Journal of Instructional Technology and Educational Studies, 1(1), 16-19. doi: 10.21608/ihites.2020.28705.1004

[9] El-ahwal, M., Shahin, A. (2020). Using video-Based on Tasks for Improving Mathematical Practice and supporting the productive struggle in Learning Math among Student Teachers in the Faculty of Education. International Journal of Instructional Technology and Educational Studies, 1(1), 26-31. doi: 10.21608/ihites.2020.29051.1013

[10] Shahin, A. (2020). Employing infographics based on tablet applications to improve professional competence in the light of the digital transformation of education technology specialists. International Journal of Instructional Technology and Educational Studies, 1(1), 23-25. doi: 10.21608/ihites.2020.28769.1006 